\title{
Vanhoja pihasyreeni- ja koristeomenakantoja Helsingin puistoissa
}

\author{
Leena Lindén ${ }^{1}$, Laura Hauta-aho ${ }^{1}$, Inka Juntheikki-Palovaara ${ }^{1}$, Outi Temmes ${ }^{2}$ ja Satu Tegel ${ }^{3}$ \\ ${ }^{1)}$ Helsingin yliopisto, soveltavan biologian laitos, PL 27, 00014 Helsingin yliopisto, \\ leena.linden@helsinki.fi,laura.hauta-aho@helsinki.fi,inka.juntheikki@helsinki.fi \\ ${ }^{2)}$ outi.temmes@gmail.com \\ ${ }^{3)}$ Helsingin kaupunki, rakennusvirasto, PL 1515,00099 Helsingin kaupunki, satu.tegel@hel.fi
}

\section{Tiivistelmä}

Helsingin puistoissa kasvaa runsas valikoima puu- ja pensaskantoja ja -lajikkeita. Tässä tutkimuksessa kartoitettiin Helsingin vanhojen viheralueiden pihasyreenejä ja koristeomenapuita. Tutkimuksen tavoitteena oli etsiä kiinnostavimmat syreeni- ja koristeomenakannat, kuvata niiden morfologiset ominaisuudet, tehdä niille DNA-sormenjäljet ja selvittää, mitä lajiketta tai lajikeryhmää ne edustavat. Tutkimus toteutettiin vuosina 2005-2009.

Arkistomateriaalin, puistoinventaarioiden ja asiantuntijahaastattelujen perusteella valittiin lähemmin tutkittaviksi 60 syreenipensasta ja 30 koristeomenapuuta. Kaikkien tutkimuskasvien morfologiset tuntomerkit mitattiin, kasvit valokuvattiin ja merkittiin kartoille ja niistä kerättiin näytteet herbaariota ja DNA-analyysejä varten. Alustava käsitys Suomessa tarjolla olleesta lajikevalikoimasta saatiin vanhan puutarhakirjallisuuden ja taimistoluetteloiden avulla. Tutkimuskasvien morfologisia ominaisuuksia verrattiin keskenään ja kirjallisuudesta löytyviin lajikekuvauksiin.

Pihasyreenit jaettiin ulkoisten ominaisuuksiensa perusteella 30 fenotyyppiryhmään. Ryhmistä kahdeksan kyettiin alustavasti nimeämään joksikin tunnetuksi lajikkeeksi. Yleisimpiä tutkimusaineistossa olivat lajikkeita 'Andenken an Ludwig Späth', 'Mme Lemoine' ja 'Michel Buchner' muistuttavat pihasyreenit. Muut nimetyt lajiketyypit olivat 'Charles Joly', 'Katherine Havemeyer', 'Krasavitsa Moskvy', 'Lemoinei' ja 'Prince Notger'. Näistä kiinnostavimpia ovat historialliset, jo viljelystä kadonneet 'Lemoinei' ja 'Prince Notger' sekä Suomenlinnan todennäköisesti hyvin vanha pihasyreenityyppi. Pihasyreeneille on kehitetty mikrosatelliittimerkit DNA-analyysiä ja lajikemääritysten varmentamista varten.

Tutkittujen koristeomenien joukossa oli 24 puna- ja 6 valkokukkaista puuta. Kaikkiaan 16 puuyksilöä määritettiin morfologisten ominaisuuksiensa avulla johonkin lajikkeeseen, lajikeryhmään, risteymään tai lajiin kuuluvaksi. Mikrosatelliittimerkkien avulla seitsemän puun määritystulos vahvistui ja kahdeksan puun märitys osoittautui virheelliseksi. Yhdelle puista ei löytynyt vertailumateriaalia. Osa tutkimusaineiston puista on otettu lisäykseen jo 1990-luvulla. Näiden lajikeidentiteettiä ei tässä tutkimuksessa kyetty varmistamaan. Uusia lisäämisen arvoisia puita löytyi nyt vähintään viisi, joukossa ensimmäisiin Rosybloom-lajikkeisiin kuuluva 'Nipissing' ja historiallinen Malus ×arnoldiana.

\footnotetext{
Asiasanat

DNA-sormenjäljet, geenivarat, genotyyppi, mikrosatelliittimerkit, pensaat, puistot, puut.
} 


\section{Johdanto}

Vanhoista puistoista ja puutarhoista löytyy kauniita, historiallisia kasviyksilöitä ja -kantoja, joiden lajiketta tai alkuperää ei enää tunneta. Vuosikymmeniä paikallisissa ilmasto- ja maaperäoloissa säilyneet, hyvin menestyvät kasvit edustavat puutarhatalouden arvokasta geenivarantoa, jonka suojeluun ja kestävään käyttöön maamme on sitoutunut. Vanhoja kasvikantoja tarvitaan historiallisia puistoja kunnostettaessa ja esimerkiksi jälleenrakennuskauden viheralueita peruskorjattaessa. Löytökasveista parhailla on kysyntää ja käyttöä monenlaisessa viherrakentamisessa (Alanko \& Tegel 1989, Tegel 2000, Juhanoja ym. 2001). Kasvigeenivarojen suojelun ja kestävän käytön edellytyksenä on, että vanhojen kasvikantojen tuntomerkit kuvataan ja niiden lajikeidentiteetti selvitetään.

Pihasyreeniä (Syringa vulgaris L.) on viljelty Suomessa 1700-luvulta alkaen. Vanhin säilynyt tieto kertoo syreenejä tuodun Turkuun vuonna 1728 (Kalm \& Högman 1756). Viipurissa kasvatettiin syreenejä 1750-luvulla, ja Suomenlinnassa tiedetään olleen syreenejä 1760-luvulla (Suominen 1997, Ruoff 2001). 1800-luvun lopulla pihasyreeni oli maamme yleisin koristepensas, jota kasvoi Etelä- ja Länsi-Suomessa torppienkin pihoilla, muualla vain herrasväen puutarhoissa (Elfving 1897). Ensimmäiset pihasyreenilajikkeet tulivat meillä myyntiin 1870-luvulla (Nummi 2005). Vanhojen taimistoluetteloiden ja arkistotietojen perusteella Suomessa on ollut käytössä vähintään 65 syreenilajiketta.

Koristeomenapuilla (Malus Mill.) tarkoitetaan sellaisia omenapuun suvun pienihedelmäisiä lajeja, lajikkeita ja risteymiä, joita viljellään ensisijaisesti koristekasveina. Talvenkestäviä, pienihedelmäisiä marja- ja siperianomenapuita (Malus baccata (L.) Borkh. ja M. prunifolia (Willd.) Borkh.) ja niiden muunnoksia on kasvatettu Suomessa ainakin 1800-luvun jälkipuoliskolta lähtien (Statsjernvägarnas Trädskolor 1879, M. G. Stenius 1886). Näitä "siperialaisia" omenapuita arvostettiin sekä kauneutensa että talouskäyttöön sopivien hedelmiensä vuoksi (Heikel 1908). Ensimmäisiä lajienvälisistä risteytyksistä syntyneitä koristeomenalajikkeita testattiin Lepaan puutarhaopistolla jo 1910-luvulla (Heikel 1919), tosin lähinnä hedelmänviljelystä silmällä pitäen. Taimistoluetteloissa risteymäperäisiä lajikkeita ja uusia koristeomenapuulajeja alkoi esiintyä 1930-luvulla (B. M. Schalinin taimisto 1937, Paul Olsson 1937, Mustilan taimitarhat 1939).

Helsingin viheralueiden koristekasvilajisto on runsas ja monipuolinen. Vuosina 1985-1995 toteutettujen KESKAS-tutkimusten yhteydessä Helsingistä rekisteröitiin noin 250 arvokkaana tai kiinnostavana pidettyä kasvikantaa, pääasiassa koristepensaita (Alanko \& Tegel 1989, Tegel 2000). Sittemmin Helsingissä on inventoitu viheralueiden puita (Alanko 2000, Mustiala 2003 ja 2005) ja puistojen kunnostus- ja kehittämissuunnitelmien yhteydessä on tehty lukuisia kasvillisuuskartoituksia.

Aikaisempien selvitysten perusteella oli tiedossa, että Helsingissä kasvaa erikoisia pihasyreenejä ja koristeomenapuita. Tämän tutkimuksen tavoitteena oli etsiä kiinnostavimmat syreeni- ja omenatyypit, kuvata niiden morfologiset ominaisuudet, kehittää niille DNA-sormenjäljet ja selvittää, mitä lajiketta tai lajikeryhmää ne edustavat. Päämääränä oli arvokkaiden genotyyppien dokumentointi ja säilyttäminen. Tutkimus toteutettiin vuosina 2005-2009 rakennusviraston katu- ja puisto-osaston ja Helsingin yliopiston soveltavan biologian laitoksen yhteistyönä.

\section{Aineisto ja menetelmät}

Tutkimuksen aluksi käytiin läpi Helsingin puistoista tehdyt kasvillisuuskartoitukset, joiden perusteella päätettiin kenttätutkimusten kohteet. Kiinnostavimpina pidettiin vanhoja istutuksia, joista valittiin tutkittaviksi mahdollisimman monennäköisiä kasviyksilöitä. Tutkittavien puiden ja pensaiden lopullinen valinta tehtiin kentällä kukinnan aikaan. Koristeomenapuiden kohdalla keskityttiin punakukkaisiin puihin. Muita omenapuiden valintakriteereitä olivat kukinnan runsaus ja puun kunto. Kaikkiaan tutkittaviksi valittiin 60 pihasyreeniyksilöä 19 puistossa ja 30 koristeomenapuuta 15 kohteessa. Lisäksi mitattiin kaksi Helsingin yliopiston kasvitieteellisessä puutarhassa kasvavaa pihasyreenin luonnonkannan pensasta, joista toisella oli siniset, toisella valkoiset kukat. Nämä syreenit on lisätty Bulgarian vuoristosta kerätystä siemenestä.

Tutkimuskasveista mitattiin kukkiin, kukintoihin, lehtiin ja hedelmiin liittyviä morfologisia tuntomerkkejä. Lisäksi havainnoitiin kasvutapaa, koristearvoa ja terveyttä. Pihasyreeneistä mitattiin yhteensä 30 muuttujaa, joista 22 liittyi kukkiin ja kukintoihin. Koristeomenapuiden dokumentoinnissa 
sovellettiin kansainvälisen kasvinjalostajanoikeusjärjestön suosituksia (UPOV 2003). Omenapuista havainnoitiin kasvutapa ja mitattiin 13 kukkiin, 12 lehtiin ja 10 hedelmiin liittyvää ominaisuutta. Mittauksissa käytettiin apuna viivainta, työntömittaa ja värikarttaa (Royal Horticultural Society 2001). Pihasyreenien kukkamittaukset tehtiin kesäkuussa, muut mittaukset elokuussa 2005. Koristeomenista mitattiin kukkien ominaisuudet kesäkuussa, lehtien ominaisuudet heinäkuussa ja hedelmien ominaisuudet syys-lokakuussa 2006. Kaikki tutkimuskasvit valokuvattiin digitaalikameralla; lähikuvissa käytettiin apuna standardiharmaakorttia. Kasvien tarkka sijainti merkittiin kartoille, jotka vietiin Helsingin kaupungin rakennusviraston katu- ja puisto-osaston paikkatietopohjaiseen pensasrekisteriin. Tutkimuskasveista kerättiin herbaarionäytteet kukinnan aikaan.

Kukkiin ja kukintoihin liittyvissä mittauksissa kerranteita oli kolme, lehtien ja hedelmien ominaisuudet mitattiin viitenä kerranteena kasviyksilöä kohden. Syreenien kukkatuntomerkit mitattiin täysin avautuneista, valossa kasvavista kukinnoista eri puolilta pensaita. Koristeomenapuiden kukka-, lehti- ja hedelmänäytteet pyrittiin keräämään latvuksen keskiosista, puun aurinkoiselta puolelta. Kukkien ominaisuuksia ei mitattu kukintosarjan keskimmäisestä, ensimmäisenä avautuvasta kukasta, joka usein poikkeaa kooltaan sarjan muista kukista. Lehtituntomerkit mitattiin vuosikasvaimen neljännestä, viidennestä tai kuudennesta lehdestä. Hedelmistä mitattiin niiden suurin pituus ja leveys.

DNA-analyysejä varten kaikista kasveista kerättiin näytteeksi noin 10 nuorta lehteä, jotka pakattiin muovipusseihin ja pakastettiin $-20^{\circ} \mathrm{C}$ :seen. DNA-analyyseissä käytettiin mikrosatelliitteihin perustuvaa menetelmää. Koristeomenien DNA-sormenjäljet tehtiin tarhaomenalle (Malus domestica Borkh.) kehitettyjen optimoitujen mikrosatelliittialukkeiden avulla (Gianfranceschi ym. 1998, Liebhard ym. 2002). Syreeneille ei ole valmiita spesifejä mikrosatelliittialukkeita, joten ne identifioitiin pihasyreenin genomista ISSR-menetelmällä (Korpelainen ym. 2007).

Pihasyreenejä verrattiin aluksi kahteen mitattuun luonnonkannan yksilöön. Lajikkeiksi oletetuille pensaille etsittiin nimiä vertaamalla niiden morfologisia ominaisuuksia kirjallisuudessa (McKelvey 1928, Meyer 1952, Bartum 1959, Krüssmann 1960 ja 1986b, Rubcov ym. 1980, Kalva 1988, Dvorak 1992, Bennet 2002, Fiala 2002) esitettyihin lajikekuvauksiin, valokuviin ja piirroksiin. Pihasyreenit luokiteltiin kukkien ja kukintojen morfologisten tuntomerkkien perusteella 30 ryhmään, joista 25 oli suhteellisen yhtenäisiä. Loput viisi ryhmää koostuivat sekalaisista pensaista, joita yhdisti ainoastaan kukkien väri ja koko. Pihasyreenejä luokiteltiin myös tilastollisen ryhmittelyanalyysin avulla.

Koristeomenapuiden morfologisessa tunnistuksessa käytettiin Den Boerin (1959), Krüssmannin (1986a), Beanin (1981) ja Fialan (1994) kirjoissa julkaistuja taksonikuvauksia. Tutkimuspuita verrattiin myös keskenään ja fenotyypiltään samannäköiset yksilöt yhdistettiin ryhmiksi. Morfologisiin piirteisiin perustuvat määritykset vahvistettiin analysoimalla tutkimuspuiden ja kasvitieteellisistä kokoelmista saatujen verrannenäytteiden DNA-sormenjälkiä. Verranteiksi hankittiin niitä taksoneja, joita tutkimuspuiden uskottiin morfologisten tuntomerkkiensä perusteella edustavan. Verrannenäytteet $(15 \mathrm{kpl})$ saatiin Helsingin ja Turun yliopistojen kasvitieteellisistä puutarhoista, Montrealin kasvitieteellisestä puutarhasta ja Dominionin arboretumista Kanadan Ottawassa. Sekä morfologisten mittausten että DNAanalyysien tulokset käsiteltiin hierarkisella ryhmittelyanalyysillä.

\section{Tulokset}

Pihasyreenien 25 yhtenäisestä ryhmästä kahdeksalle löytyi alustava lajikenimi morfologisten ominaisuuksien perusteella (Taulukko 1). Tätä kirjoitettaessa syreenien DNA-tulokset eivät ole vielä käytettävissä. Nimettyihin lajiketyyppiryhmiin kuului kaikkiaan 20 pensasta. Ne poikkesivat pihasyreenin perusmuodosta kukan kerrannaisuuden tai värin tai molempien osalta. Kukan laidekehän läpimitta oli näillä pensailla keskimäärin $21 \mathrm{~mm}$, kun se sinikukkaisella luonnonkannan yksilöllä oli keskimäärin 13 $\mathrm{mm}$ ja valkokukkaisella $16 \mathrm{~mm}$. 
Taulukko 1. Pihasyreenin lajiketyyppiryhmät, niihin kuuluvat pensaat ja pensaiden keskeiset tuntomerkit. Taulukossa Y tarkoittaa yksinkertaisia, K kerrannaisia kukkia. Mittaustulokset ovat kolmen kerranteen keskiarvoja.

\begin{tabular}{|c|c|c|c|c|c|}
\hline $\begin{array}{l}\text { Tyyppiryhmän } \\
\text { nimi }\end{array}$ & $\begin{array}{l}\text { Pensaan } \\
\text { numero }\end{array}$ & $\begin{array}{l}\text { Kukan } \\
\text { kerran- } \\
\text { naisuus }\end{array}$ & Väriryhmä & $\begin{array}{l}\text { Kukan laide- } \\
\text { kehän läpimitta } \\
\text { mitta, mm }\end{array}$ & $\begin{array}{l}\text { Kukinnon } \\
\text { pituus, cm }\end{array}$ \\
\hline Andenken an & 44 & $\mathrm{Y}$ & punainen & 19 & 16 \\
\hline \multirow[t]{3}{*}{ Ludwig Späth } & 45 & $\mathrm{Y}$ & punainen & 22 & 24 \\
\hline & 26 & Y & punainen & 18 & 15 \\
\hline & 35 & $\mathrm{Y}$ & punainen & 23 & 21 \\
\hline Charles Joly & 43 & $\mathrm{~K}$ & punainen & 20 & 17 \\
\hline \multicolumn{6}{|l|}{ Havemeyer } \\
\hline Krasavitsa Moskvy & vy 13 & $\mathrm{~K}$ & valkoinen & 25 & 20 \\
\hline Lemoinei & 2 & K & sinipunainen & 13 & 10 \\
\hline \multirow[t]{4}{*}{ Michel Buchner } & 28 & $\mathrm{~K}$ & sinipunainen & 20 & 22 \\
\hline & 31 & $\mathrm{~K}$ & sinipunainen & 19 & 19 \\
\hline & 23 & $\mathrm{~K}$ & sininen & 22 & 16 \\
\hline & 55 & $\mathrm{~K}$ & sininen & 20 & 16 \\
\hline \multirow[t]{5}{*}{ Mme Lemoine } & 10 & K & valkoinen & 17 & 13 \\
\hline & 21 & K & valkoinen & 20 & 17 \\
\hline & 37 & $\mathrm{~K}$ & valkoinen & 22 & 16 \\
\hline & 46 & $\mathrm{~K}$ & valkoinen & 22 & 18 \\
\hline & 62 & K & valkoinen & 23 & 21 \\
\hline \multirow[t]{3}{*}{ Prince Notger } & 48 & Y & sininen & 20 & 23 \\
\hline & 52 & $\mathrm{Y}$ & sininen & 21 & 22 \\
\hline & 59 & $\mathrm{Y}$ & sininen & 21 & 19 \\
\hline
\end{tabular}

Nimeä vaille jääneisiin 17 tyyppiryhmään kuului yhteensä 24 syreenipensasta. Näillä kukan laidekehän läpimitta oli keskimäärin $22 \mathrm{~mm}$. Yksi pensaista oli kerrannaiskukkainen, muilla oli yksinkertaiset kukat. Kaikki 24 erosivat siinä määrin pihasyreenin perusmuodosta kukan värin tai kukinnon muodon ja koon perusteella, että niiden uskottiin edustavan jotakin lajiketta tai viljelykantaa, mutta kirjallisuudesta ei löydetty niitä vastaavia kuvauksia. Loput 16 tutkittua syreenipensasta olivat keskenään erilaisia ja suhteellisen pienikukkaisia (laidekehän läpimitta keskimäärin $17 \mathrm{~mm}$ ).

Lähes puolet tutkituista pensaista ( $27 \mathrm{kpl}$ ) oli kukiltaan sinipunaisia. Valkokukkaisia pensaita oli 15 , sinikukkaisia 12 ja punakukkaisia kuusi. Kukkien kerrannaisuuden, värin ja koon lisäksi syreenipensaiden välillä oli eroja laideliuskojen muodossa ja niiden asennossa kukkatorveen nähden. Kukinnoissa oli eroja pituuden, leveyden ja tiheyden suhteen.

Koristeomenapuista 16 määritettiin morfologisten tuntomerkkien perusteella johonkin lajiin, lajikeryhmään tai lajikkeeseen kuuluvaksi. Kaikille tutkimus- ja verrannepuille onnistuttiin tekemään DNA-sormenjäljet käyttämällä yhdeksää mikrosatelliittialuketta, jotka kopioivat 12:ta lokusta. Lokuskohtaisiin alleelikokoihin perustuva ryhmittelyanalyysi vahvisti seitsemän puun taksonimäärityksen oikeaksi (Taulukko 2). Yhden tutkimuspuun lajikemääritystä ei voitu testata DNA-merkkien avulla, koska sille ei onnistuttu hankkimaan verrannenäytettä. Kahdeksan puun ulkoisiin tuntomerkkeihin perustuva määritys ei saanut tukea DNA-analyysin tuloksista. 
Taulukko 2. Morfologisten piirteiden ja DNA-merkkien avulla tunnistetut koristeomenapuut keskeisine tuntomerkkeineen. Kukkien läpimitat ovat kolmen, hedelmien läpimitat viiden kerranteen keskiarvoja. Tähti (*) tarkoittaa puuttuvaa tietoa.

\begin{tabular}{|c|c|c|c|c|c|c|c|c|}
\hline $\begin{array}{l}\text { Taksonin } \\
\text { nimi }\end{array}$ & $\begin{array}{l}\text { Puun } \\
\text { numero }\end{array}$ & $\begin{array}{l}\text { Ryhmän } \\
\text { tunnus }\end{array}$ & $\begin{array}{l}\text { Nuorten } \\
\text { lehtien } \\
\text { väri }\end{array}$ & $\begin{array}{l}\text { Terälehtien } \\
\text { sisäpinnan } \\
\text { väri }\end{array}$ & $\begin{array}{l}\text { Kukan } \\
\text { läpimitta } \\
\text { mm }\end{array}$ & $\begin{array}{l}\text { Hedelmän } \\
\text { kuoren } \\
\text { väri }\end{array}$ & $\begin{array}{l}\text { Hedelmän } \\
\text { läpimitta } \\
\text { mm }\end{array}$ & $\begin{array}{l}\text { Verhiön } \\
\text { säilyminen } \\
\text { hedelmässä }\end{array}$ \\
\hline Malus & 7 & A & punaruskea & vaaleanpunainen & 45 & punakeltainen & 27 & säilyy \\
\hline \multirow[t]{2}{*}{ 'Nipissing' } & 13 & A & punaruskea & vaaleanpunainen & 48 & punakeltainen & 36 & säilyy \\
\hline & 22 & A & punaruskea & vaaleanpunainen & 48 & punakeltainen & 33 & säilyy \\
\hline Malus & 21 & B & punaruskea & vaaleanpunainen & 47 & punaoranssi & 18 & säilyy \\
\hline 'Hopa' & 23 & B & punaruskea & vaaleanpunainen & 43 & $\begin{array}{l}\text { oranssin- } \\
\text { keltainen }\end{array}$ & 23 & säilyy \\
\hline Malus 'Eleyi' & 24 & $\mathrm{E}$ & punaruskea & keskipunainen & 40 & $*$ & $*$ & $*$ \\
\hline $\begin{array}{l}\text { Malus } \\
\text { ×arnoldiana }\end{array}$ & 29 & $\mathrm{D}$ & $\begin{array}{l}\text { vaalean- } \\
\text { vihreä }\end{array}$ & valkoinen & 52 & punakeltainen & 11 & $\begin{array}{l}\text { säilyy } \\
\text { harvoin }\end{array}$ \\
\hline
\end{tabular}

Morfologisten ominaisuuksien perusteella puut jaettiin viiteen ryhmään (A, B, C, D ja E), joista neljä ensinmainittua olivat kohtalaisen yhtenäisiä, ja viidenteen (ryhmään $E$ ) kuuluivat loput 21 keskenään erilaista puuta. DNA-vertailut osoittivat, että ryhmän A kolme ja ryhmän B kaksi puuta olivat lähes tai täysin identtisiä sekä keskenään että verrannelajikkeidensa kanssa (Taulukko 2). Ryhmän C muodostivat kaksi valkokukkaista, morfologisia tuntomerkkejä käyttäen marjaomenapuiksi määritettyä puuta. Toinen näistä oli DNA-sormenjälkien perusteella läheistä sukua verranteina käytetyille marjaomenapuille. Toinen taas muistutti sormenjäljiltään enemmän siperian- kuin marjaomenapuita. Ryhmään D luokiteltiin kaksi puuta, jotka muistuttivat ulkonaisesti Malus $\times$ arnoldianaa ja toista tämän risteymälajin vanhemmista, ruusuomenapuuta ( $M$. floribunda Siebold ex Van Houtte). DNA-vertailut osoittivat toisen puista identtiseksi M. ×arnoldianan kanssa (Taulukko 2), mutta toinen erosi näistä lähes kaikkien tutkittujen lokusten osalta.

Tunnistamatta jääneiden koristeomenapuiden joukossa oli joitakin yksilöitä, jotka näyttivät DNAvertailun perusteella olevan läheistä sukua toisilleen. KESKAS-lajikkeella 'Rixi' oli niin samanlaiset sormenjäljet kuin puulla numero 9, että toinen niistä voi olla toisen jälkeläinen. Myös KESKAS-lajikkeille 'Kuohu' ja 'Kirjailija' löytyi kummallekin tutkimuspuiden joukosta yksi lähisukulainen. KESKASlajikkeet 'Linnanmäki' ja 'Tumma Kaunotar' sekä yksi tutkimuspuista muodostivat kolmen puun sukulaisryhmän.

Kaikilla tunnistetuilla omenapuilla oli yksinkertaiset kukat. Kerrannaiskukkaisia puita oli koko aineistossa viisi, joista yksi oli valkokukkainen. Kaikkiaan tutkimusaineistoon kuului kuusi valkokukkaista ja 24 punakukkaista puuta. Väriryhmien sisällä oli vaihtelua värin voimakkuudessa ja terälehtien sekä kukan muodossa.

\section{Tulosten tarkastelu}

Helsingin viheralueilta löytyi 25 sellaista pihasyreenityyppiä, joiden uskottiin edustavan jotakin lajiketta tai viljelykantaa. Historiallisesti kiinnostavimpiin kuuluvat tyyppiryhmien 'Lemoinei', 'Prince Notger' ja P64 pensaat. 'Lemoinei' on ensimmäisiä ranskalaisen Victor Lemoinen risteyttämiä kerrannaiskukkaisia lajikkeita, joka laskettiin kauppaan vuonna 1878. Sata vuotta sitten lajiketta käytettiin hyötösyreeninä (Heikel 1907). Sitä on myös arkistotietojen perusteella istutettu Helsingin puistoihin 1900-luvun alkupuoliskolla. Tässä tutkimuksessa löydetty 'Lemoinei'-tyypin pensas kasvoi Annalan huvilan puutarhurin talon päädyssä, minne se on hyvinkin voinut päätyä hyödön jälkeen. 'Lemoinei' ja jo ennen vuotta 1841 erään belgialaisen prinssin mukaan nimetty 'Prince Notger' ovat kadonneet viljelystä. 'Prince 
Notger' on vanhimpia Suomessa kaupan olleita pihasyreenilajikkeita; se mainitaan Molanderin siemenkaupan luettelossa vuonna 1877 (Nummi 2005). P64-tyyppi edustaa Suomenlinnan vanhaa pihasyreenikantaa. Suomenlinnan lisäksi P64-tyypin pensaita tavattiin Herttoniemen ja Stansvikin kartanoiden alueilta sekä Pihlajasaaren vanhalta huvila-alueelta. Kaikista neljästä paikasta, ja osittain samoista istutuksista, löytyi myös Prince Notger -tyypin pensaita. Todennäköisesti näiden istutusten ja pihasyreenityyppien taustassa on yhteisiä tekijöitä.

Pihasyreenilajikkeiden tunnistaminen morfologisten tuntomerkkien perusteella osoittautui vaikeaksi. Pihasyreenistä tunnetaan kaikkiaan lähes 2000 lajiketta, eikä useimpia niistä ole kuvattu kirjallisuudessa riittävän tarkasti (Fiala 2008). Syreenilajikkeiden tärkeimmät tuntomerkit liittyvät kukkien ja kukintojen kokoon, muotoon ja väriin. Vanhoissa lajikekuvauksissa kukista mainitaan usein vain kokoluokka (pieni, keskikokoinen, suuri), ja kokoon vaikuttavat genotyypin lisäksi ympäristötekijät ja kasvin ikä. Eri lähteiden lajikekuvauksissa on osittain ristiriitaisia tietoja, mikä voi johtua siitä, että syreenilajikkeita on toisinaan lisätty suvullisesti, jolloin jälkeläiset saattavat olla samankaltaisia, mutteivät enää identtisiä emoyksilön kanssa.

Värien kuvaamista on pyritty standardisoimaan värikartoilla, jollaista käytetään myös vanhimmassa syreenilajikkeiden tarkkaan kuvaamiseen pyrkivässä julkaisussa (McKelvey 1928). Väristandardit ovat kuitenkin muuttuneet niin paljon, ettei McKelveyn värikuvauksia ole enää mahdollista tulkita luotettavasti. Kukkien väri muuttu kehitysasteen myötä, ja siihen vaikuttavat myös maaperän happamuus ja karkeus sekä kukinta-ajan sää (Fiala 2008). - Tutkittujen pihasyreenien lajikemääritykset ja syreenityyppien yhtenäisyys varmistuvat, kun DNA-tutkimukset saadaan päätökseen.

Mikrosatelliittimerkein varmennetuista koristeomenapuista 1920-luvulla kauppaan tulleet 'Hopa' ja 'Eleyi' ovat olleet meillä yleisesti viljeltyjä (Kallio 1966 ja 1984). Molempia lisätään kotimaisissa taimistoissa edelleen ja niitä on arkistotietojen perusteella istutettu Helsinkiin ainakin 1940-luvun lopulta lähtien. Marja- ja ruusuomenapuun spontaani risteymä Malus ×arnoldiana syntyi 1880-luvulla Arnoldin arboretumissa Massachusetissa. Tämän tutkimuksen Malus ×arnoldiana löytyi Kulosaaren Kramerinlehdosta, jonka suunnitteli vuonna 1953 silloinen kaupunginpuutarhuri Bengt Schalin. Schalin on ylistänyt 'Eleyitä' ja Malus xarnoldianaa kirjoituksissaan (Schalin 1934 ja 1936). Malus xarnoldianaa on ollut myynnissä C. T. Wardin taimitarhalla 1914-1916 ja Mustilan taimitarhoilla 1930-luvulla. Kallion koristepuiden levinneisyyttä selvittävässä tutkimuksessa (1966) Malus xarnoldiana mainitaan vain Seinäjoelta.

'Nipissing' on vuonna 1930 nimetty kanadalainen Rosybloom-sarjan lajike, jota tiedetään istutetun muutamiin kohteisiin Helsingissä 1940- ja 1950-luvuilla. Muualle Suomeen lajiketta on istutettu vähän, ja sen menestyminen on ollut kohtalaista tai tyydyttävää (Kallio \& Karhiniemi 1977, Kallio 1984). Kirjallisuudessa 'Nipissingiä' kuvaillaan isokokoiseksi pensaaksi (Kallio \& Karhiniemi 1977, Krüssmann 1986a), mutta kaikki kolme Helsingistä löydettyä puuta olivat pystykasvuisia ja omenapuiksi huomattavan suuria. Ehkä perusrungolla on erikoisen suuri vaikutus tämän lajikkeen kasvuun. 'Nipissingiä' ei enää löydy taimistojen valikoimista. Sitä, samoin kuin 'Hopaa', 'Eleyitä' ja Malus ×arnoldianaa, pidetään ulkomaisessa kirjallisuudessa hyvin ruvenalttiina (Fiala 1994, Pettersson 2001). Tämän tutkimuksen puista omenarupea havaittiin häiritsevissä määrin vain KESKAS-lajikkeella 'Kirjailija' .

Helsingin puistoista rekisteröitiin KESKAS-tutkimuksen aikana seitsemän koristeomenapuuta, joita lisätään kotimaisilla taimistoilla. Yhdellekään näistä ei tässä tutkimuksessa löydetty lajikenimeä. Viidelle KESKAS-puulle löytyi DNA-sormenjälkien perusteella lähisukulainen tutkimuspuiden joukosta, mikä tukee oletusta, että KESKAS-lajikkeista ainakin osa on syntynyt kaupunginpuutarhuri Schalinin risteytyskokeilujen tuloksena.

\section{Kirjallisuus}

Alanko, P. 2000. Helsingin puistojen uhanalaiset ja harvinaiset, viljelynarvoiset puut. Sorbifolia 31: 141-149.

Alanko, P. \& Tegel, S. 1989. KESKAS-tutkimus. Kestäviä koristekasveja viherrakentamisen tarpeisiin. SITRA, sarja B, nro 98: $111 \mathrm{~s}$.

Bartum, D. 1959. Lilac and Laburnum. London, John Gifford. 175 s.

Bean, W. J. 1981. Trees and shrubs hardy in the British Isles. Vol. 2. $8^{\text {th }}$ revised edition, $3^{\text {rd }}$ corrected impression. 
London, John Murray. $784 \mathrm{~s}$.

B. M. Schalinin taimisto 1937. Hintaluettelo. $32 \mathrm{~s}$.

Bennett, J. 2002. Lilacs for the garden. New York, Fireflybooks. 127 s.

Den Boer, A. F. 1959. Ornamental crab apples. Washington D.C., The American Association of Nurserymen. 226 s.

Dvorak, J. 1992. Lilac study - a four year study at Lilacia park, the Morton arboretum etc. (Ed. Fiala, J. 1978 \& Rodgers, O. 1992.) Auburn, ME, International Lilac Society. $84 \mathrm{~s}$.

Elfving, F. 1897. Anteckningar om kulturväxterna i Finland. Acta Societatis pro Fauna et Flora Fennica 14(2): 1116.

Fiala, J. L. 1994. Flowering crabapples, the genus Malus. Portland, Timber Press. 273 s.

Fiala, J. L. 2002. Lilacs: the Genus Syringa. Portland, Timber Press. 266 s.

Fiala, J. L. 2008. Lilacs: a gardender's encyclopedia. 2. p. Toim. F. Vrugtman. Portland, Timber Press. 416 s.

Gianfranceschi, L., Seglias, N., Tarchini, R., Komjanc, M. \& Gessler, C. 1998. Simple sequence repeats for the genetic analysis of apple. Theoretical and Applied Genetics 96: 1069-1076.

Heikel, B. W. 1907. Sireenipensaan kasvatus ja hyötäminen. Puutarha 10: 94-95.

Heikel, B. W. 1908. Hedelmä- ja marjanviljelyn opas. Helsinki, Otava. 124 s.

Heikel, B. W. 1919. Hedelmän- ja marjanviljelys avomaalla. 2., lisätty painos. Helsinki, Otava. $261 \mathrm{~s}$.

Juhanoja, S., Aaltonen, M., Aflatuni, A., Heinonen, A., Kemppainen, R., Paasikivi, P., Sorvari, K., Vehkalahti, M. \& Virtanen, A. 2001. Tutkittuja kasveja viherrakentamisen tarpeisiin. MTT:n julkaisuja, sarja A 98: $60 \mathrm{~s}$.

Kallio, T. K. 1966. Koristepuiden ja -pensaiden levinneisyydestä ja menestymisestä Suomessa. Annales Agriculturae Fenniae 5, Suppl. 1: $107 \mathrm{~s}$.

Kallio, T. K. 1984. Suomessa koristekasveina viljellyistä omenapuulajeista ja -lajikkeista. Sorbifolia 15: 9-17.

Kallio, T. K. \& Karhiniemi, A. 1977. Omenapuut (Malus) koristekasveina. Puutarhantutkimuslaitoksen tiedote 10: 28-36.

Kalva, V. 1988. Sirelid. Tallinn, Valgus. 175 s.

Kalm, P. \& Högman, D. E. 1756. Trän till häckar eller lefwande gärdes-gårdar. Åbo. $22 \mathrm{~s}$.

Korpelainen, H., Kostamo, K. \& Virtanen, V. 2007. Microsatellite marker identification using genome screening and restriction-ligation. BioTechniques 42: 479-486.

Krüssmann, G. 1960. Vorbereiten für eine Flieder-Sichtung, Teil 2. Deutsche Baumschule 12(4): 89-108.

Krüssmann, G. 1986a. Manual of cultivated broad-leaved trees and shrubs. Vol. 2. Portland, Timber Press. 445 s.

Krüssmann, G. 1986b. Manual of cultivated broad-leaved trees and shrubs. Vol. 3. Portland, Timber Press. 510 s.

Liebhard, R., Gianfranceschi, L., Koller, B., Ryder, C. D., Tarchini, R., Van de Weg, E. \& Gessler, C. 2002. Development and characterisation of 140 new microsatellites in apple (Malus $\times$ domestica Borkh.) genome. Theoretical and Applied Genetics 106: 1497-1508.

McKelvey, S. D. 1928. The lilac. New York, Macmillan Company. 581 s.

Meyer, F. 1952. Flieder. Garten und Weinbau, Heft 102: 98 s.

M. G. Stenius 1886. Pris-kurant. 8 s.

Mustiala, V. 2003. Helsingin lehmukset. Helsingin kaupungin rakennusviraston julkaisuja 2003(5): $68 \mathrm{~s}$.

Mustiala, V. 2005 Helsingin lehtipuut. Helsingin kaupungin rakennusviraston julkaisuja 2005(6): $88 \mathrm{s.}$

Mustilan taimitarhat 1939. Hintaluettelo. $73 \mathrm{~s}$.

Nummi, A. 2005. Syringa-lajit ja -lajikkeet Suomen taimikaupassa. Julkaisematon kooste. $12 \mathrm{~s}$.

Paul Olsson 1937. Hinnasto. $46 \mathrm{~s}$.

Pettersson, M.-L. 2001. Skorv på vedartade växter. SLU faktablad om växtskydd 128 T. 4 s.

Royal Horticultural Society 2001. RHS colour chart. London, The Royal Horticultural Society. $221 \mathrm{~s}$.

Rubcov, L. I., Michailov, N. L. \& Zogolava, V. G. 1980. Vidy' sorta sireni kul'tivituemye v SSSR. Kiev, Naukova Dumka. $129 \mathrm{~s}$.

Ruoff, E. 2001. Vanhoja suomalaisia puutarhoja. Helsinki, Otava. 238 s.

Schalin, B. 1934. Malus (omenapuun) suku. Puutarha 37: 168-170.

Schalin, B. 1936. Sällsynta buskar och småträd under odling i södra Finland. Svensk Botanisk Tidskrift 30: $373-385$. Statsjernvägarnes Trädskolor 1879. Katalog öfver träd och buskar i Statsjernvägarnes Trädskolor vid Hyvinge. Painamaton, käsin kirjoitettu luettelo.

Suominen, O. 1997. Syreeni, muiston tyyssija. Teoksessa: Pekonen, O. (toim.). Elämän puu. Porvoo, WSOY. s. 275-297.

Tegel, S. 2000. Helsingin puistojen kestävät kaunottaret. KESKAS-raportti. Helsinki, Helsingin kaupungin rakennusvirasto. $112 \mathrm{~s}$.

UPOV 2003. Ornamental apple (Malus Mill.), Guidelines for the conduct of tests for distinctness, uniformity and stability. Geneva, International union for the protection of new varieties of plants (UPOV). $27 \mathrm{~s}$. 